\title{
EDITORIAL
}

\section{A saúde e os direitos de trabalhadores}

Mais uma vez a Saúde, Ética \& Justiça traz temas importantes, em sintonia com o momento em que vivemos. Neste número, a saúde e os direitos de trabalhadores constituíram-se em foco dos estudos.

Em tempos de importantes mudanças no mundo do trabalho e de revisão dos direitos trabalhistas, é muito oportuno o estudo de Gonsalez e colaboradores, que chama a atenção para as condições em que atuam os médicos residentes. No texto é feita uma comparação de alguns aspectos da Consolidação das Leis Trabalhistas (CLT) com os seus correspondentes na regulamentação da residência médica no país, mostrando a situação de precariedade a que os residentes se veem expostos.

$\mathrm{O}$ afastamento das atividades laborais por transtorno mental atinge um grande número de trabalhadores, e tem consequências para eles, para empresas e para a sociedade como um todo. O retorno ao trabalho após afastamento devido a adoecimento é uma situação que impõe diversos desafios, especialmente em se tratando de transtornos mentais. Programas que visem a favorecer o sucesso do retorno de trabalhadores às suas atividades poderiam prestar uma valiosa contribuição, mas, infelizmente, ainda são raros no país. Pettoruti e Faiman se dedicam a essa questão realizando uma revisão do que tem sido feito a esse respeito.

O Brasil é um país de grande produção agrícola e o uso de agrotóxicos é amplamente disseminado. Muito se tem discutido a respeito da liberação ou não da aplicação de determinadas substâncias nas plantações em função da nocividade que podem conferir aos produtos delas derivados. Os trabalhadores agrícolas compõem uma categoria profissional mais direta e incisivamente afetada pelos agrotóxicos. O estudo de Vieira, Vieira e Sá nos mostra o quanto a saúde desses trabalhadores tem sido negligenciada em função da falta de estratégias de cuidado especificamente dirigidas para esta população.

Atualmente, no Brasil, o transporte de cargas é predominantemente rodoviário. O número de acidentes nas estradas e a expressividade da parcela desses em que estão envolvidos caminhões são grandes. A qualidade da acuidade visual do motorista é um dos fatores a serem verificados quando se pensa em redução de acidentes. A partir disso, fica clara a importância do alerta contido no artigo Alterações visuais encontradas em uma amostra de caminhoneiros nas rodovias do estado de São Paulo, em que se constataram relevantes alterações visuais nas pessoas avaliadas, todas elas em plena atividade como motoristas.

Encerrando este número, temos o relato de uma intervenção ergonômica bem-sucedida, aplicada em centros de educação infantil, com vistas a diminuir a sobrecarga da região lombar na atividade de troca de fraldas de crianças, que é cotidianamente realizada por professoras e auxiliares destes centros.

Desejo a todos uma boa leitura!

Carla Júlia Segre Faiman Editora assistente 